\title{
Risk and Trade Regimes: Another Exploration
}

\section{Citation}

Bates, Robert H., Philip Brock, and Jill Tiefenthaler. 1991. Risk and trade regimes: Another exploration. International Organization 45, no. 1: 1-18.

\section{Published Version}

http://dx.doi.org/10.1017/S0020818300001375

\section{Permanent link}

http://nrs.harvard.edu/urn-3:HUL.InstRepos:3219934

\section{Terms of Use}

This article was downloaded from Harvard University's DASH repository, and is made available under the terms and conditions applicable to Other Posted Material, as set forth at http:// nrs.harvard.edu/urn-3:HUL.InstRepos:dash.current.terms-of-use\#LAA

\section{Share Your Story}

The Harvard community has made this article openly available.

Please share how this access benefits you. Submit a story.

Accessibility 


\section{Risk and trade regimes: another exploration \\ Robert H. Bates, Philip Brock, and Jill Tiefenthaler}

Two major bodies of literature focus on the relationship between trade and government policy and, in so doing, take contrasting positions. One originates in political science and stresses the way in which government activism enhances openness to international markets; this literature focuses on the small open economies of Western Europe. The other originates in development economics and emphasizes the limits placed by government intervention on international trade; this literature focuses on the experiences of developing nations. Perhaps because these bodies of literature are drawn from different disciplines and examine different kinds of nations, the debates between them have not openly been joined. In this article, we make explicit the opposing positions. Even more important, we attempt to reconcile their discordance. We do so by grounding our analysis on the role of risk in structuring institutional relationships.

In recent years, the field of development economics has been swept by a neoclassical revival. In an earlier era, development economists condemned markets and called for government intervention, arguing that the imperfections and failure of markets justified "big pushes" by governments.' By contrast, the present-day development literature stresses the virtues of markets, even in poor societies, and highlights the losses in economic welfare produced by policy-related distortions of market prices. ${ }^{2}$ Arnold Harberger's

Research for this article was supported by the National Science Foundation (grant no. SES 8821151 ) and the Ford Foundation. We thank Peter Lange, Stephen Krasner, Joseph Grieco, and several anonymous referees for their comments and criticisms and are grateful to Carlos Contreras for his research assistance.

I. See Paul N. Rosenstein-Rodan, "Problems of Industrialization of Eastern and SouthEastern Europe," Economic Journal 52 (Summer 1943), pp. 202-11; and Tibor Scitovsky, "Two Concepts of External Economies," in A. N. Agarwala and P. Singh, eds., The Economics of Underdevelopment (London: Oxford University Press, 1963), pp. 295-337.

2. See Deepak Lal, The Poverty of 'Development Economics' (London: Institute of Economic Affairs, 1984); and Ian Little, Economic Development (New York: Basic Books, 1982). For 
1985 review of the experiences of the developing countries since World War II, for example, drew a dozen or so lessons for policymakers, over twothirds of which counsel against an activist role for governments. ${ }^{3}$

Nowhere is the contemporary condemnation of government intervention more sharply focused than on barriers to international trade. Arguing against those whom Deepak Lal and Ian Little characterize as "trade pessimists," Bela Balassa and Anne Krueger have endorsed openness to international markets as a means of promoting economic growth and facilitating rapid recovery from external economic shocks. ${ }^{4}$ And as recorded in the efforts of the World Bank and the International Monetary Fund to alter domestic economic policies in developing nations, international agencies have mounted a concerted campaign against political barriers to international trade, seeking thereby to promote the greater use of markets. ${ }^{5}$

In striking contrast to the literature in development economics stands the literature in political science on the small trading economies of Western Europe. Rather than highlighting the negative role of government intervention on economic growth, this literature has instead stressed its positive contributions. This is particularly true of government interventions that affect openness to international trade. As stated by Peter Katzenstein, "The experience of the small European states suggests that political intervention . . . does not constrain but complements international liberalization."

The literature on the small open economies of Western Europe explores the internal, political basis for the maintenance of open trade regimes. Focusing on the relations between large firms, organized labor, and government, one strand has examined how the structure of corporatist interest group relations promotes peaceful patterns of economic policy adjustment in response to shifting patterns of comparative advantage in foreign markets. ${ }^{7}$ A second strand has explored the size of government, by which is meant

contrasting viewpoints, see Joseph E. Stiglitz, "Markets and Development," working paper no. 2961, National Bureau of Economic Research, 1989; and Kevin M. Murphy, Andrei Shliefer, and Robert W. Vishny, "Industrialization and the Big Push," Journal of Political Economy 97 (October 1989), pp. 1003-26.

3. Arnold C. Harberger, "Economic Policy and Economic Growth," in Arnold C. Harberger. ed., World Economic Growth (San Francisco: Institute for Contemporary Studies, 1985). pp. 427-66.

4. See Lal, The Poverty of 'Development Economic's'; Little, Economic Development; Bela Balassa, "The Newly Industrializing Countries After the Oil Crisis," Weltwirtschaftliches Archiv, vol. 117, 1981, pp. 142-94; and Anne Krueger, Development with Trade (San Francisco: Institute for Contemporary Studies, 1988).

5. See Joan M. Nelson, The Politics of Economic Adjustment in Developing Nations (Princeton, N.J.: Princeton University Press, 1988); and John Williamson. IMF Conditionality (Washington, D.C.: Institute for International Economics, 1983).

6. Peter Katzenstein, "The Small European States in the International Economy: Economic Dependence and Corporatist Politics," in John Gerard Ruggie, ed., The Antimonies of Interdependence (New York: Columbia University Press, 1983), p. 103.

7. See Philippe C. Schmitter, "Interest Intermediation and Regime Governability in Contemporary Western Europe and North America," in Suzanne Berger, ed., Organizing Interests in Western Europe (Cambridge: Cambridge University Press, 1981), pp. 285-327: David R. Cameron, "The Expansion of the Public Economy: A Comparative Analysis." American Po- 
the relative size of the public economy. Rather than finding minimalist governments, characterized by fiscal prudence and financial restraint, contributors to this literature have instead found large governments in countries possessing market-oriented international trade regimes. As David Cameron noted in his study of the sources of growth of the governments of eighteen advanced industrialized nations, "Nations with open economies were far more likely to experience an increase in the scope of public funding than were nations with relatively closed economies"; expenditures on income supplements and social insurance constituted a major source of the expansion of the public economy. ${ }^{8}$

In analyzing the role of governments in promoting openness to international markets, the two bodies of literature have thus taken strikingly different positions. In attempting to reconcile the discordant views, we turn to a third body of literature: that on the impact of risk on the structuring of institutions. As underscored in the recent writings of Oliver Williamson and others, risk and the availability of instruments for dealing with it shape the structure of nonmarket institutions. ${ }^{9}$ In the absence of complete markets for risk, this literature contends, rational actors who are risk averse will structure nonmarket institutions-governance structures, in the words of Williamson-in an effort to reduce the welfare losses incurred from variability in economic environments. ${ }^{10}$

Employing this perspective, Williamson and others have analyzed the structure of institutions as diverse as the firm, the law, lineages and households, contracts, and government agencies. ${ }^{11}$ Economists have also applied this analysis to international trade. Indeed, in few other fields has the "Williamsonesque" perspective been so fully developed. A major consequence is that we can employ the study of trade protection to assess the power of this mode of theorizing.

litical Science Review 72 (December 1978), pp. 1243--61; and David R. Cameron, "Social Democracy, Corporatism, Labour Quiescence, and the Representation of Economic Interest in Advanced Capitalist Society," in John H. Goldthorpe, ed., Order and Conflict in Contemporary Capitalism (Oxford: Oxford University Press, 1984), pp. 143-78. See also the following articles by Geoffrey Garett and Peter Lange: "Performance in a Hostile World: Domestic and International Determinants of Economic Growth in Advanced Capitalist Democracies, 1974-1982," World Politics 38 (July 1986), pp. 517-45; "Government Partisanship and Economic Performance: When and How Does 'Who Governs' Matter?" Journal of Politics 51 (August 1989), pp. 676-93; and "The Politics of Growth: Strategic Interaction and Economic Performance in the Advanced Industrial Democracies, 1974-1980," Journal of Politics 47 (August 1985), pp.
$792-827$.

8. See Cameron, "The Expansion of the Public Economy," p. 1253.

9. See Oliver Williamson, The Economic Institutions of Capitalism (New York: Free Press, 1985). See also the collection of articles in Louis Putterman, ed., The Economic Nature of the
Firm (Cambridge: Cambridge University Press, 1986).

10. See Williamson, The Economic Institutions of Capitalism.

11. For an analysis of the structure of the law, see Paul R. Milgrom, Douglass C. North, and Barry R. Weingast, "The Role of Institutions in the Revival of Trade: The Law Merchant, Private Judges, and the Champagne Fairs," Economics and Politics 2 (March 1990), pp. 1-24. Regarding lineages and households, see Richard Posner, "A Theory of Primitive Society," Journal of Law and Economics 23 (April 1980), pp. 1-53; Hans P. Binswanger and Mark R. 
Economic trade theorists have noted that in the face of terms-of-trade risk, national economies-when modeled as single agents-can reduce exposure to international markets by shifting toward autarky. ${ }^{12}$ Subsequent studies by David Newbery and Joseph Stiglitz and by Jonathan Eaton and Gene Grossman have demonstrated that in the presence of terms-of-trade risk and in the absence of complete domestic markets for insurance, governments can improve welfare by employing tariffs; but they have also demonstrated that if governments were able to make transfers from one set of agents to another, then free trade would be optimal. ${ }^{13}$

In this article, we adopt a "Williamsonesque" perspective to explain the response of domestic governments to the risks engendered by the fluctuation of prices in international markets. The international economic environment, we argue, poses not only opportunities for gains from trade but also the danger of risk. One method of coping with this risk is protectionism. Another consists of domestic forms of insurance: welfare and transfer payments.

Our analysis of a sample set of thirty-two countries shows that the higher the level of terms-of-trade risk that a nation faces in international markets, the more likely it is to increase trade barriers. It also shows that the greater the social insurance programs mounted by a nation's government, the less likely that government is to block free trade. While stressing the limited quality of the data and the empirical analysis that the data can support, we nonetheless note the implications of our findings. One is that the solutions to the problem of terms-of-trade risk which are emphasized in the studies of the small open economies of Western Europe may not readily extend to the developing areas. Countries in the developing world may remain protectionist because they lack the resources to mount internal programs of transfer payments as a means of coping with risk from international markets. Another implication is a heightened respect for the power of the new institutionalism, as promoted by Williamson and others. Analyzing tariff pro-

Rosensweig, "Behavioral and Material Determinants of Production Relations in Agriculture," Report no. ARU 5, Agriculture and Rural Development Department, World Bank, 1984; and Robert Pollack, "A Transaction Cost Approach to Families and Households," Journal of Economic Literature 23 (June 1985), pp. 581-608. Regarding contracts, see Paul Joskow, "Productivity Growth and Technical Change in the Generation of Electricity, " working paper, Center for Energy Policy Research, Massachusetts Institute of Technology, 1985. Regarding government agencies, see Matthew D. McCubbins and Terry Sullivan, Congress: Structure and Policy (Cambridge: Cambridge University Press, 1987).

12. See James E. Anderson and John G. Riley, "International Trade with Fluctuating Prices," International Economic Review 17 (February 1976), pp. 76-97. See also Jonathan Eaton, "The Allocation of Resources in an Open Economy with Uncertain Terms-of-Trade," International Economic Review 20 (June 1979), pp. 391-403.

13. See David Newbery and Joseph Stiglitz, The Theory of Commodity Price Stabilization: A Study in the Economics of Risk (Oxford: Oxford University Press, 1981), chap. 23; and Jonathan Eaton and Gene Grossman, "Tariffs as Insurance: Optimal Commercial Policy When Domestic Markets Are Incomplete," Canadian Journal of Economics 18 (May 1985), pp. 258-72. See also the following articles by Avinash Dixit: "Trade and Insurance with Moral Hazard," Journal of International Economics 23 (November 1987), pp. 201-20; and "Trade and Insurance with Imperfectly Observed Outcomes," Quarterly Journal of Economics 104 (Winter 1989), pp. 195-203. 
tection and domestic transfers as alternative responses to market risk enables us to find a common theoretical basis on which to ground the divergent bodies of literature on trade and protection and to reconcile the dispute between them.

It is important to realize that studies of the small open economies of Western Europe constitute but one part of a much wider literature on the domestic sources of protection. One way of characterizing contributions to this literature is by noting whether they locate trade policy in the polity or in society. Another is by noting the unit of analysis that they employ: the sector, the industry, or the factor of production. Stephen Krasner, for example, imputes the sources of trade policy to national political institutions and focuses on the industry. ${ }^{14}$ Ronald Rogowski, by contrast, locates the origins of trade policy in societal interests and focuses on the factors of production. ${ }^{15}$ Wendy Hansen sees both political and societal interests at play and locates the origins of protectionism in the demands of specific industries. ${ }^{16}$ In this article, we remain agnostic as to the unit of analysis, and we view trade policy as originating from both national political and societal sources. Economic agents, we argue, are averse to risk. And governments, seeking to maximize the social welfare, implement policies to reduce risk but are constrained in the policies they can choose by the policy instruments at their command. ${ }^{17}$

This article thus draws on but a small subset of a much larger literature. It does so because the political scientists who study the small open economies of Western Europe dissent so strongly from the position of economists who focus on the Third World and because these differences impel us to focus on a deeper theoretical issue: the relationship between risk and the formation of nonmarket institutions.

\section{The data set}

Our data set is built around the sample of countries studied in the World Development Report, 1987. ${ }^{18}$ This World Bank study and the background papers from which it was compiled evaluated the trade policies of forty-one

14. Stephen D. Krasner, Defending the National Interest (Princeton, N.J.: Princeton Uni-
ersity Press, 1978). ersity Press, 1978).

15. Ronald Rogowski, Commerce and Coalitions (Princeton, N.J.: Princeton University
Press, 1989).

16. Wendy Hansen, "The International Trade Commission and the Politics of Protectionism," American Political Science Review 84 (March 1990), pp. 21-46.

17. For a treatment that adumbrates the principal themes of this article, see the approach taken by Stephen Krasner in the following works: "State Power and the Structure of International Trade," World Politics 28 (January 1976), pp. 317-47; and Structural Conflict: The an able review of much of the broader literatey: University of California Press, 1985). For Theory: A Critical Survey," American literature, see Douglas Nelson, "Endogenous Tariff 796-837.

18. World Bank, World Development Report, 1987 (New York: Oxford University Press, 
TABLE 1. Countries classified by trade regime maintained over the periods 1963-73 and 1974-84

Trade policy classification ${ }^{\mathrm{a}}$

\begin{tabular}{|c|c|c|c|c|}
\hline Period & $\begin{array}{l}\text { Strongly } \\
\text { inward } \\
\text { oriented }\end{array}$ & $\begin{array}{c}\text { Moderately } \\
\text { inward } \\
\text { oriented }\end{array}$ & $\begin{array}{c}\text { Moderately } \\
\text { outward } \\
\text { oriented }\end{array}$ & $\begin{array}{l}\text { Strongly } \\
\text { outward } \\
\text { oriented }\end{array}$ \\
\hline $1963-73$ & $\begin{array}{l}\text { Argentina } \\
\text { Chile } \\
\text { Ethiopia } \\
\text { India } \\
\text { Peru } \\
\text { Sri Lanka } \\
\text { Tanzania } \\
\text { Uruguay }\end{array}$ & $\begin{array}{l}\text { Bolivia } \\
\text { El Salvador } \\
\text { Honduras } \\
\text { Kenya } \\
\text { Mexico } \\
\text { Nicaragua } \\
\text { Philippines } \\
\text { Tunisia } \\
\text { Yugoslavia }\end{array}$ & $\begin{array}{l}\text { Brazil } \\
\text { Colombia } \\
\text { Costa Rica } \\
\text { Guatemala } \\
\text { Israel } \\
\text { Malaysia } \\
\text { Thailand }\end{array}$ & $\begin{array}{l}\text { Austria } \\
\text { Belgium } \\
\text { Denmark } \\
\text { Korea } \\
\text { Netherlands } \\
\text { Norway } \\
\text { Sweden } \\
\text { Switzerland }\end{array}$ \\
\hline $1974-84$ & $\begin{array}{l}\text { Argentina } \\
\text { Bolivia } \\
\text { Ethiopia } \\
\text { India } \\
\text { Peru } \\
\text { Tanzania }\end{array}$ & $\begin{array}{l}\text { Colombia } \\
\text { Costa Rica } \\
\text { El Salvador } \\
\text { Guatemala } \\
\text { Honduras } \\
\text { Kenya } \\
\text { Mexico } \\
\text { Nicaragua } \\
\text { Philippines } \\
\text { Sri Lanka } \\
\text { Yugoslavia }\end{array}$ & $\begin{array}{l}\text { Brazil } \\
\text { Chile } \\
\text { Israel } \\
\text { Malaysia } \\
\text { Thailand } \\
\text { Tunisia } \\
\text { Uruguay }\end{array}$ & $\begin{array}{l}\text { Austria } \\
\text { Belgium } \\
\text { Denmark } \\
\text { Korea } \\
\text { Netherlands } \\
\text { Norway } \\
\text { Sweden } \\
\text { Switzerland }\end{array}$ \\
\hline
\end{tabular}

The trade policies of twenty-five of the countries listed in this table were classified by the World Bank in its World Development Report, 1987 (New York: Oxford University Press, 1987), p. 83. Those of the remaining seven-Austria, Belgium, Denmark, the Netherlands, Norway, Sweden, and Switzerland-were categorized as strongly outward oriented on the basis of the World Bank classification system.

countries in terms of their degree of protection, with criteria including the extent of use of quantitative controls and trade licensing, the level and incidence of the effective rates of protection, and the degree of overvaluation of the exchange rate. ${ }^{19}$ It classified each country's trade regime according to whether it was strongly inward oriented (category 1), moderately inward oriented (category 2), moderately outward oriented (category 3), or strongly outward oriented (category 4) during two periods, 1963-73 and 1974-84.

19. See David Greenaway, "World Development Report, 1987: Background Paper for Chapter 4," unpublished manuscript, World Bank, November 1986. 
The World Bank's classification provided relatively systematic data on trade policies, one of the variables of greatest significance to our study and one for which little systematic information was available from other sources. We therefore attempted to build a data set by collecting additional information about these forty-one countries. Limitations in the data reduced the number of usable cases to twenty-five. ${ }^{20}$ Of the countries classified by the World Bank as strongly outward oriented, Korea was the only one for which the needed data were available. Our inclusion of seven of the small open countries of Western Europe-Australia, Belgium, Denmark, the Netherlands, Norway, Sweden, and Switzerland-increased the number of observations in this category. The thirty-two countries in our data set, classified by trade regime, are shown in Table 1.

\section{The dependent and independent variables}

The variables employed in this study, as well as their units and the sources from which they were taken, are shown in Table 2.

In addition to analyzing trade policies (TP) as a dependent variable, we analyzed the actual level of openness to international trade. As a measure of openness, we used the logarithm of the average ratio of exports plus imports to the gross national product, multiplied by 100 (LOpen).

The two major independent variables, measured as described below, were the instability in international terms of trade (LInst) and the level of per capita transfer payments made by the government (LTrpa).

For the first of these independent variables, we attempted to construct an empirical measure of terms-of-trade instability that would capture the capacity of economic agents to make rational forecasts of the terms of trade and of their conditional variance. To that end, we ran a regression of the terms of trade against their lagged value for the period 1963-84. We found that the coefficients of the lagged values were close to 1.0. When we applied the unit root methods outlined by David Dickey and Wayne Fuller, we could not reject the hypothesis that the terms of trade for the countries followed a random walk. ${ }^{21}$ In addition, when we used Lagrange multiplier tests of the residuals, we could not reject the hypothesis that the residuals were white noise. The standard errors of the autoregressions provided an empirical

20. The primary difficulty was assembling data regarding each variable for each nation over a sufficiently long period. Other empirical studies, starting with Alasdair MacBean's Export Instability and Economic Development (London: Allen \& Unwin, 1966), have used export figures to derive various measures of export instability. The studies then examined the empirical correlations between export instability and variables such as saving, investment, and rate of growth of the gross domestic product. Since we wanted to study the relationship between risk and public policy, we chose to use our measure of terms-of-trade risk rather than work with
measures of export instability.

21. David A. Dickey and Wayne A. Fuller, "Likelihood Ratio Statistics for Autoregressive Time Series with a Unit Root," Econometrica 49 (July 1981), pp. 1057-72. 
TABLE 2. Variables, units, and sources

Dependent variables

LOpen Logarithm of the ratio of exports plus imports to gross national product. in the countries' own currencies, average in 1963-73 for the first period and in 1974-84 for the second period, multiplied by 100 . Source: International Monetary Fund, International Financial Statistics Yearbook (Washington, D.C.: International Monetary Fund, 1980 and 1986).

TP

Trade policy, as classified according to the World Bank system. Source: World Bank, World Development Report, 1987 (New York: Oxford University Press, 1987).

Independent variables

Linc

Logarithm of per capita income, in U.S. dollars, in 1973 for the first period and in 1981 for the second period. Source: Mark S. Hoffman, ed., World Almanac and Book of Facts, 1989 (New York: Pharos Books. 1989).

LInst

Logarithm of the level of instability in the terms of trade, in 1963-73 for the first period and in 1974-84 for the second period. Source: International Monetary Fund, International Financial Statistics Yearbook: and Comisión Económica para America Latina, America Latina: Relación de precios del intercambio (Latin America: Terms of trade) (Santiago, Chile: Naciónes Unidas, 1976).

LPop Logarithm of the population in tens of millions, in 1973 for the first period and in 1981 for the second period. Source: International Monetary Fund. International Financial Statistics Yearbook.

LRev

Logarithm of per capita revenues collected from sources other than trade, in millions of U.S. dollars, in 1973 for the first period and in 1981 for the second period. Source: International Monetary Fund, Government Financial Statistics Yearbook (Washington, D.C.: International Monetary Fund, 1981).

LTrpa Logarithm of per capita transfer payments made by the government, in millions of U.S. dollars, in 1973 for the first period and in 1981 for the second period. Source: International Monetary Fund, Government $\mathrm{Fi}^{-}$ nancial Statistics Yearbook.

a For LInc, LPop, LRev, and LTrpa, regressions were based on data for 1981 (rather than 1984, the last year of the second period) because 1984 data were not available for all of the countries in the study. 
TABLE 3. Instability measures ${ }^{\mathrm{a}}$

\begin{tabular}{|c|c|c|}
\hline Country & $1963-73$ & $1974-84$ \\
\hline Argentina & 8.64 & 6.38 \\
\hline Austria & 2.56 & 4.00 \\
\hline Belgium & 2.09 & 2.00 \\
\hline Bolivia & 6.18 & 10.82 \\
\hline Brazil & 11.01 & 14.43 \\
\hline Chile & 21.09 & 17.81 \\
\hline Colombia & 6.71 & 19.72 \\
\hline Costa Rica & 5.23 & 6.52 \\
\hline Denmark & 2.53 & 5.00 \\
\hline El Salvador & 25.99 & 22.72 \\
\hline Ethiopia & 8.51 & 20.44 \\
\hline Guatemala & 5.68 & 13.10 \\
\hline Honduras & 3.53 & 11.53 \\
\hline India & 5.89 & 17.51 \\
\hline Israel & 7.80 & 6.13 \\
\hline Kenya & 7.30 & 16.63 \\
\hline Korea & 2.35 & 7.74 \\
\hline Malaysia & 13.55 & 9.06 \\
\hline Mexico & 4.74 & 8.92 \\
\hline Netherlands & 1.75 & 1.36 \\
\hline Nicaragua & 5.28 & 12.81 \\
\hline Norway & 1.35 & 5.35 \\
\hline Peru & 8.89 & 12.83 \\
\hline Philippines & 8.55 & 12.50 \\
\hline Sri Lanka & 15.35 & 26.30 \\
\hline Sweden & 1.52 & 4.26 \\
\hline Switzerland & 4.93 & 5.21 \\
\hline Tanzania & 15.74 & 14.84 \\
\hline Thailand & 2.96 & 10.90 \\
\hline Tunisia & 3.28 & 5.45 \\
\hline Uruguay. & 24.31 & 12.23 \\
\hline Yugoslavia & 1.72 & 2.41 \\
\hline Average & 7.719 & 10.841 \\
\hline Standard deviation & 6.430 & 6.250 \\
\hline
\end{tabular}

"The instability measures are the standard errors of the following forecasting equation:

$$
\text { TOT }_{t}=a_{0}+a_{1} \text { TOT }_{t-1}+u_{t}
$$

with TOT, denoting the terms of trade in year $t$ and with $u_{t}$ denoting the error term. 
measure of terms-of-trade instability whose theoretical counterpart is the variance of forecast errors made by rational agents. This measure therefore captured a theoretically well-grounded notion of risk. ${ }^{22}$ Table 3 lists the instability measures for the thirty-two countries in our data set during the periods examined by the World Bank, 1963-73 and 1974-84. ${ }^{23}$

For the second major independent variable, we gathered data on the magnitude of government payments to individuals, families, and firms, including unemployment insurance and "bailouts," to use American terminology. ${ }^{24}$ We then expressed the measure as a logarithm of the per capita value of transfer payments in millions of U.S. dollars.

Additional independent variables included in the study and described in Table 2 were per capita income (LInc), population (LPop), and per capita revenues (LRev).

\section{Relationships among variables}

The relationships among variables are summarized in Table 4.

Equation 1 in the table shows the results of our first exploration of the relationship between risk and protectionism. In addition to including a variable to measure terms-of-trade instability, we controlled for the impact of population and per capita income. ${ }^{25}$ The size, sign, and significance of the

22. One referee asked why we did not use either the degree of concentration of exports or the level of export of primary materials as a measure of risk. We offer three responses. We tried the first, and it bore no systematic relation to our measure of trade protection. Insofar as either measure is supposed to relate to protection, it is held to do so because it relates to increased levels of risk. And we measure risk directly and in a way that is consistent with the theory of risk and choice in economic behavior.

23. In order to make use of the classifications of trade regimes provided by the World Bank, our study focused on the two periods $1963-73$ and 1974-84. Because of the small number of observations in each period, we could not employ the unit root or white noise residual tests. To assess the validity of our measure within the two sample periods, we therefore estimated first-order and second-order autoregessions. The results obtained when we included the secondorder lag of the terms-of-trade variable were virtually identical to those obtained from the firstorder autoregression. The empirical results that we report in this article therefore use the standard error of first-order autoregressions as the measure of terms-of-trade instability.

A referee contended that the real factor distinguishing the developed economies was the existence of futures markets for handling price risk. However, as is well known, such markets are incomplete. It is partly for this reason that the advanced countries devote so large an amount of their resources to programs of social insurance, as is documented in the data employed in this research.

24. Data were obtained from a telephone interview with Mr. Gustavo Ortiz, Department of Government Financial Statistics, Bureau of Statistics, International Monetary Fund, 2 March 1988, and from the International Monetary Fund's Government Financial Statistics Yearbook (Washington, D.C.: International Monetary Fund, 1981), Tables 10 and 13.

25 . Chenery was the first to demonstrate the importance of population as an explanatory variable for the volume of a country's international trade. See Hollis B. Chenery. "Patterns of Industrial Growth," American Economic Review 50 (March 1960), pp. 624-54. Subsequent empirical work on patterns of development has also used population as an explanatory variable for trade patterns. 
coefficient of the instability variable offered support for the hypothesis that in the absence of complete international insurance markets, the greater the level of instability in a country's terms of trade, the greater will be the movement of the country toward autarky.

But what of the actual behavior of governments? To examine this phenomenon, we explored the relationship between terms-of-trade instability and the trade policies adopted by governments, as classified by the World Bank and listed in Table 1. We proceeded in two stages (or cuts), first analyzing the trade policies of the combined set of European and developing nations for the period 1963-73 (Cut I) and then analyzing them for the period 1974-84 (Cut II). Throughout our analysis, we treated the World Bank's classification of trade regimes as an ordered, categorical variable. ${ }^{26}$ Because the dependent variable is a qualitative variable, the use of conventional regression techniques would have generated coefficients that lacked mean zero or constant variance. But because the dependent variable possesses ordinal properties, we were able to use maximum likelihood, ordered probit procedures and thereby obtain consistent and asymptotically efficient estimates of the parameters. ${ }^{27}$

\section{Empirical results: Cut I}

Equation 2 in Table 4 shows the results of the first test of the relationship between external trade risk and the choice of government policy. The magnitude and the sign of the coefficient of the variable measuring terms-oftrade instability did not allow us to reject the proposition that governments use trade policy as a means of insurance. The coefficient significantly differed from zero at the 5 percent confidence level. On the basis of this equation, 50 percent of the countries' trade regimes were classified correctly. In contrast, on the basis of chance alone, we could expect only 25-28 percent to be classified correctly. The equation thus clearly outperforms what could be achieved by chance. ${ }^{28}$

26. We assigned a 1 to the most protectionist (inward-oriented) countries and a 4 to the most open (outward-oriented) countries; we assigned a 2 or a 3 to countries with a moderately inward or moderately outward orientation, respectively.

27. The Time Series Processor (PC-TSP) Version 4.1B was used for all probit procedures and for ordinary least squares. The standard errors for the probit procedures were computed
from analytic first and second derivatives.

28. One way of evaluating our equations is in terms of the degree to which they out-perform chance. If the task of classification is viewed as an assignment problem, then random assignment of a case to one of the four categories should yield a correct classification 25 percent of the time. If the task is instead viewed as an urn problem, then the random selection of a case should yield a member of the modal category of trade regime. As seen in Table 1, the modal category over the period 1963-73-that of moderately inward oriented trade regimes-contains nine cases, or 28 percent of the cases. Viewed as an urn problem, correct classifications should be made 28 percent of the time on the basis of chance alone. 


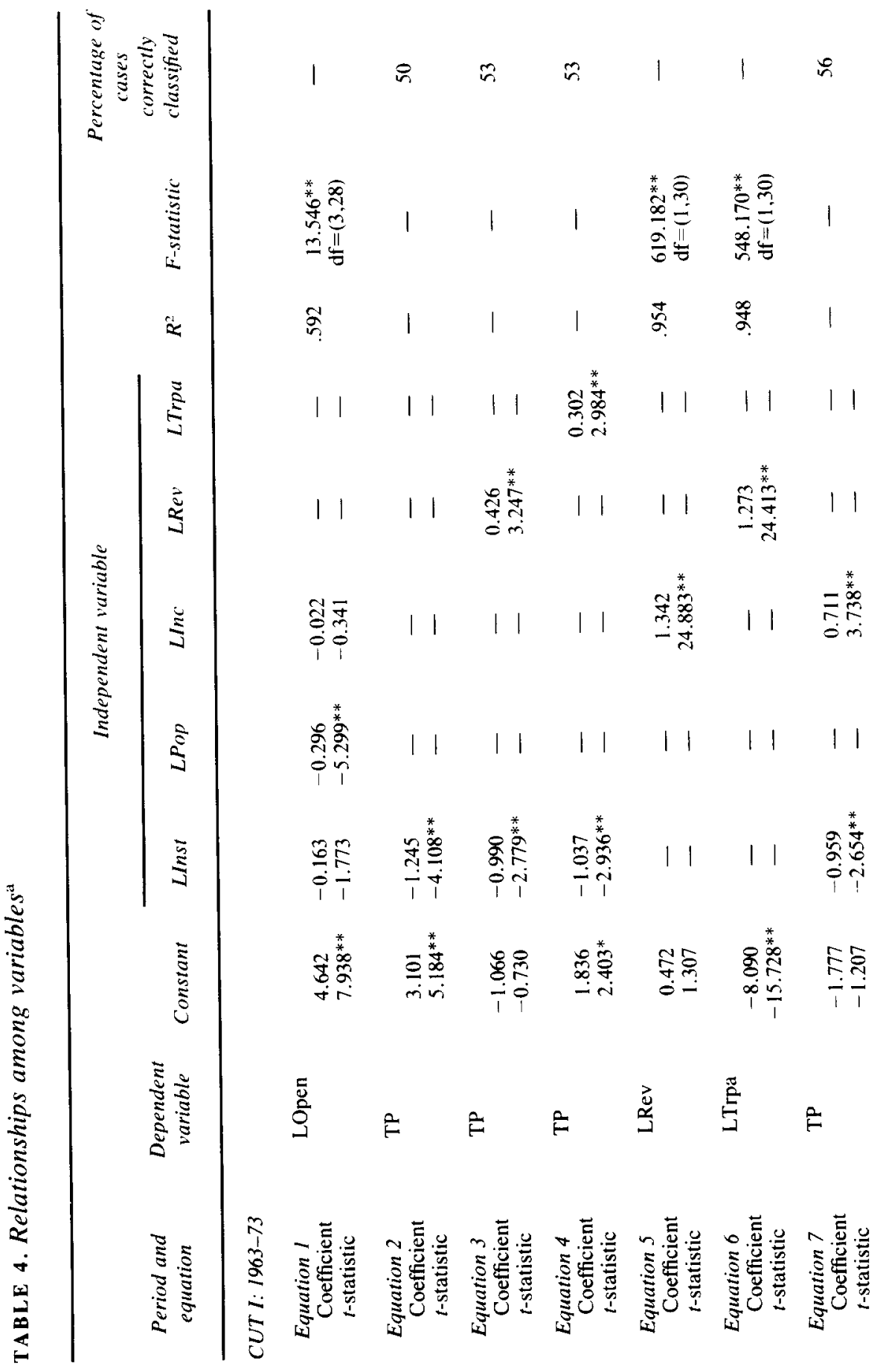




$$
\begin{aligned}
& 1+2 \pi \quad 1 \quad 18
\end{aligned}
$$

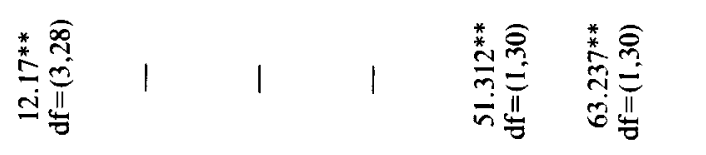

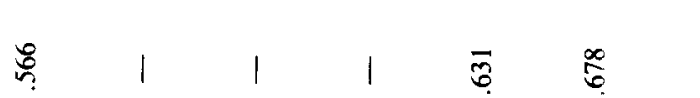

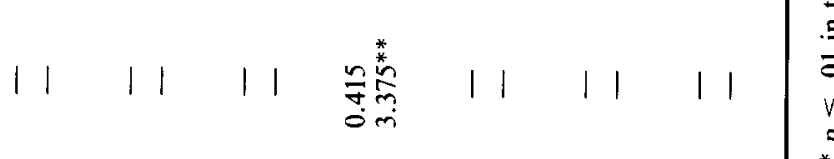

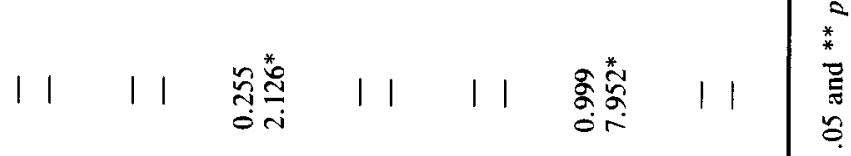

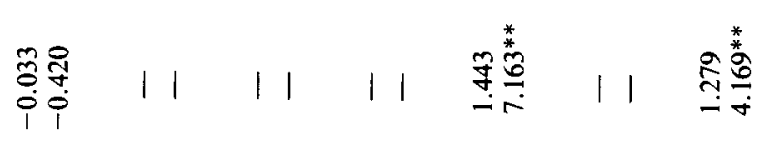

$$
\begin{aligned}
& \text { 章 } \\
& 11 \quad 11 \quad 11 \quad 11 \quad 11
\end{aligned}
$$



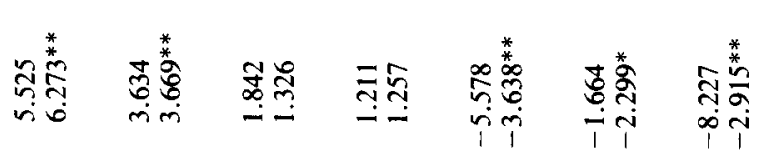

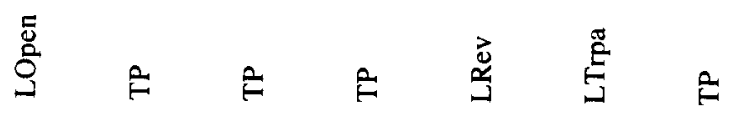

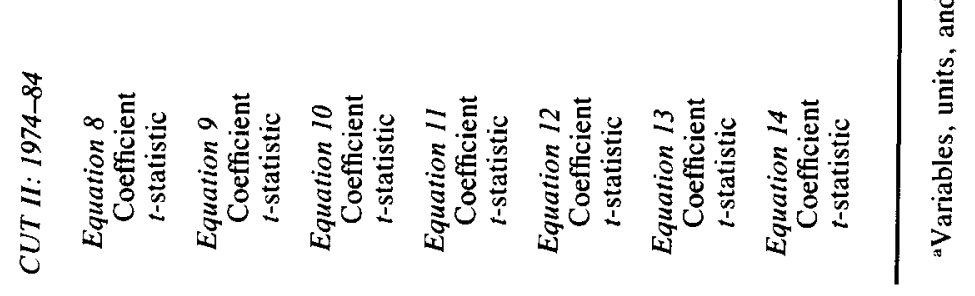


But what if governments had instruments other than trade policy at their command? We might expect governments that can insure against the risks of economic change to sustain more open trade policies. By socializing the impact of relative price variability in external markets, they might be able to persuade private economic agents to confront the risks of openness to international trade. ${ }^{29}$

One determinant of the ability of governments to insure against risks would be the magnitude of revenues at their command. In equation 3 , we therefore explored the impact of government revenues on trade policy. In measuring the level of government revenues, we computed only the per capita magnitude of the revenues collected from sources other than trade. If we had instead included revenues from tariffs and other trade sources, both our dependent and independent variables would constitute measures of trade protection. As seen in equation 3, higher levels of instability were associated with more closed trade regimes. The greater the level of government revenues, however, the greater was the tendency to be open to international markets.

To cut more deeply into the determinants of trade regime orientation, we next measured the actual efforts of governments to insure against risks. As noted by Cameron, Katzenstein, and others, the most direct measure of government efforts to socialize market risks is the level of their expenditures on social insurance..$^{30}$ Because there appeared to be little annual variation in these expenditures, we employed data from a single year, 1973. As seen in equation 4 , the signs and the magnitudes of the variables were consistent with the claim that the greater the extent to which a government makes transfer payments to socialize risks, the more open are its trade policies.

When applying probit procedures, we calculated the probabilities that a single country would fit into each of the four trade classifications. These probabilities were used in arriving at the percentage of cases correctly classified. In equation 4 , for example, the regression results showed a 15 percent chance that Argentina would fit into category 1, with chances of 38 percent for category 2, 35 percent for category 3 , and 12 percent for category 4 . Consequently, Argentina would be predicted by the regression to be moderately inward oriented (category 2), while it was classified by the World Bank as strongly inward oriented (category 1). We should note, however, that virtually all such errors in prediction were small ones, involving the

29. Grossman emphasizes the role of government transfers in developing countries when domestic insurance markets are incomplete: "An important lesson that emerges from the analysis is that the size of the risk-bearing entrepreneurial class should not, in and of itself, be a policy target in less developed economies. Rather, policy should arise to provide mechanisms by which risk can be efficiently allocated across the population." See Gene Grossman, "International Trade, Foreign Investment, and the Formation of the Entrepreneurial Class," American Economic Review 74 (September 1984). p. 613.

30. See Cameron, "The Expansion of the Public Economy": Peter Katzenstein, Corporatism and Change (Ithaca, N.Y.: Cornell University Press, 1984); and Peter Katzenstein, Small States in World Markets: Industrial Policy in Europe (Ithaca, N.Y.: Cornell University Press, 1985). See also the sources listed in footnotes 6-8 (above). 
misassignment of cases into immediately adjacent categories. There was only one case of a two-step error: Yugoslavia, predicted by the regression to be strongly outward oriented, was instead classified by the World Bank as moderately inward oriented.

The results in equations 3 and 4 thus suggest the significance for trade policies of the ability of governments to transfer resources to firms and families whose economic welfare is put at risk by unexpected fluctuations in international markets. As noted above, an important determinant of that ability is the per capita magnitude of government revenues. ${ }^{31}$ An obvious implication is that governments in poor countries might be driven to adopt protectionist policies in part because they lack access to revenues sufficient to implement major programs of social insurance. ${ }^{32}$

Equation 5 highlights the close relationship between the level of income and government revenues. Equation 6 makes clear the close relationship between the level of government revenues and expenditures on transfer payments. And equation 7 illustrates the significance of the level of income per capita and the terms-of-trade instability for the adoption of open trade regimes.

The implication of equations 5 through 7 is clear. Governments in richer countries have access to greater levels of government revenues from nontrade sources. As a consequence, it would appear, they can finance programs of social insurance more abundantly and can also maintain more open trade policies. The kinds of strategies pursued by the small open economies of Europe and documented by Cameron, Katzenstein, and others would appear simply to be unaffordable to poorer nations.

\section{Empirical results: Cut II}

Given that the empirical results for the 1963-73 data did not run counter to the expectations we formed from theory, we decided to push further and repeat the tests on data from 1974-84. As is evident in Table 3, a great deal changed over the two periods. With the second oil price shock, the collapse of the Bretton Woods system of international payments, and shifts in major commodity markets, there was a rise in the overall level of risk in international markets. Similarly, there was a rise in the relative levels of risk confronted by particular countries. For example, while Korea faced one of the more stable sets of prices in world markets during the early period, it faced one of the more unstable sets in the later period. Not only did the environment of risk change over the two periods but the trade regimes chosen by different countries changed as well (see Table 1). Chile, for example, moved from strongly inward to moderately outward oriented in its trade policies,

31. Here, as elsewhere in this article, we refer to revenues levied from sources other than international trade.

32. They may also adopt these policies because tariffs form the major source of their revenues. 
whereas Colombia became more protectionist. To test the robustness of our analysis, we therefore reestimated equations 1 through 7 for the new period.

The results for the 1974-84 period are presented in equations 8 through 14 in Table 4 . In evaluating the results of the probit estimations, it should be kept in mind that on the basis of chance alone, we could expect only 25-34 percent of the countries' trade regimes to be classified correctly. ${ }^{33}$

Equation 8 replicates equation 1 for the $1974-84$ period. $^{34}$ As was true with the data from the earlier period, the cross-sectional results do not reject the proposition that increased terms-of-trade instability leads to decreased openness. The results in equation 9 reemphasize the link between terms-oftrade instability and trade policy, a link that was evident in the analysis of the earlier data. Equation 11 shows that while external instability in international markets, as measured by terms-of-trade risk, promotes closed trade regimes, the possession of internal means of insurance, such as programs of transfer payments, promotes openness in international markets. And equations $10,12,13$, and 14 reinforce the lesson drawn from the analysis of the earlier period: richer countries are better able to provide internal means of insurance, since they can raise greater amounts of government revenue from nontrade sources and thereby finance programs of transfer payments.

It is notable, then, that despite the massive shocks to the international economy that took place in the 1974-84 period, the data drawn from that period tended to replicate the findings drawn from the $1963-73$ period. ${ }^{35}$

\section{Conclusion and disclaimers}

In recent years, two discordant bodies of literature have focused on the role of governments and orientations toward international markets. Development economists have condemned the governments of the developing nations for their activism and claimed that their policies promote stagnation through protectionism. By contrast, political scientists have praised the governments of the small open economies of Western Europe for their interventionism and claimed that their policies promote growth through trade.

33. See footnote 28 (above). In the period 1974-84, the chance of a correct assignment remains 25 percent, but the modal category of trade regime now contains 34 percent of the cases.

34. However, for LInc, LPop, L.Rev, and LTrpa, regressions were based on data for 1981 (rather than 1984, the last year of period) because 1984 data were not available for all of the countries in our study.

35. To further explore the impact of national income on the choice of trade regime, we then dropped the seven European countries from the analysis. A major problem with this procedure was that it left Korea as the sole country with a strongly outward oriented trade policy. Using this reduced data set, we found that terms-of-trade instability remained a significant explanatory variable of choice of trade regime for the period 1963-73. We also found that the magnitude of the transfer payments made by a government bore a significant relationship to the level of protectionism that it practiced in its international trade policy for the period 1974-84. But because of the small number of cases per category of the dependent variable, we cannot place much reliance on these findings. 
To achieve a more comprehensive understanding of the behavior of governments, we turned to the body of literature that focuses on risk, trade, and government policy. This literature suggests several hypotheses: In the absence of international markets for risk, countries facing higher levels of terms-of-trade instability are likely to turn toward autarky. In the absence of internal insurance markets, governments seeking to enhance economic welfare are likely to prefer protective trade policies to free trade; however, if they were able to initiate transfers among domestic agents, they might prefer free trade. Moreover, governments in countries unable to afford programs of internal transfer payments should be likely to turn toward protectionism, whereas those in countries able to mount transfer programs are likely to move toward open trade regimes and tolerate higher levels of risk from international markets. ${ }^{36}$

In conclusion, we wish to stress both the implications and limitations of our analysis. Insofar as the analysis is correct, it implies that to secure the reform of trade policies, policymakers might first improve the capacity of economic agents to secure other forms of insurance. It also implies that greater weight should be accorded to the arguments of Richard Cooper and others concerning the crafting of international organizations: to reduce protectionism and promote international trade, international institutions (such as the International Monetary Fund) should design their programs so as to enable states to accept the risks of openness. ${ }^{37}$

The findings of our analysis must be treated as suggestive at best, however, since their theoretical and empirical foundations are highly imperfect. We have not, after all, provided a causal account of how the risk preferences of individual economic agents lead to the collective choice of national trade policy. And, empirically, the data impose strong limitations. The data are based on qualitative judgments about the trade orientations of only thirtytwo countries. In our empirical work, we have taken as given the classification of countries made by the World Bank in its World Development Report, 1987. While we felt confident that the seven small European countries we added would be classified as strongly outward in orientation ac-

36. As forcefully put by one reader, it is not only the ability to pay that is at issue; it is also the willingness to do so. Some wealthy countries are unwilling to mount major transfer programs that would enable them to socialize the risks of international trade. The United States, for example, does little in comparison with, say, Sweden. This observation underscores the significance of factors that we have excluded from our analysis, such as political ideology. It also challenges us to account for variability in the behavior of governments that are wealthy and face relatively similar levels of risk. Rather than taking this comment as a hostile challenge, however, we instead view it as sympathetic. For if our analysis is correct, then inclusion of such factors should improve the performance of our models.

37. See Richard Cooper, The Economics of Interdependence (New York: McGraw-Hill, 1968). See also John Ruggie, "International Regimes, Transactions, and Change," in Stephen Krasner, ed., International Regimes (Ithaca, N.Y.: Cornell University Press, 1983), pp. 195-232; Kenneth Dam, The GATT: Law and International Organization (Chicago: University of Chicago Press, 1970); and Joseph M. Grieco, Cooperation Among Nations (Ithaca, N.Y.: Cornell University Press, 1970). 
cording to the standards used in the World Development Report, our classification clearly required further subjective judgments.

We also wish to emphasize that cross-sectional evidence of the type we have employed cannot, by itself, provide a complete test of the predictions generated by the theoretical literature on terms-of-trade instability. Even though the classification of trade regimes in the World Development Report allowed us to conduct our empirical tests for both the 1963-73 and 1974-84 periods, future work would benefit from more detailed and reliable time series analysis. And, above all, the unavailability of data severely limited our ability to model the structure of the problem and the quality and sophistication of the econometric techniques that we could employ.

The data are modest. Largely as a consequence, the statistical analysis remains both elementary and weakly linked to the theoretical argument. The results are suggestive and intriguing, however, and we therefore place them in the public domain. 